\title{
Clinical neurochemistry: developments in dementia research based on brain bank material
}

\author{
E. Perry ${ }^{1}$, J. Court ${ }^{1}$, R. Goodchild ${ }^{1}$, M. Griffiths ${ }^{1}$, E. Jaros ${ }^{2}$, M. Johnson ${ }^{1}$, \\ S. Lloyd ${ }^{1}$, M. Piggott ${ }^{1}$, D. Spurden ${ }^{1}$, C. Ballard ${ }^{1}$, I. McKeith ${ }^{3}$, \\ and R. Perry ${ }^{2}$ \\ ${ }^{1}$ Medical Research Council Neurochemical Pathology Unit, \\ ${ }^{2}$ Department of Neuropathology, and ${ }^{3}$ Institute for the Health \\ of the Elderly, Elderly Annexe, Newcastle General Hospital, \\ Newcastle upon Tyne, United Kingdom
}

Received December 12, 1997; accepted June 3, 1998

Summary. Brain tissue obtained at autopsy continues to provide unique opportunities in current dementia research. Not only is tissue analysis still essential for diagnosis, but investigation of neurochemical pathology, at a level of resolution beyond current in vivo imaging, continues to provide new insights into the involvement of neurotransmitter signalling systems. These are relevant to therapy which, with respect to symptoms such as cognitive impairment, psychosis and depression, is currently targeted to specific transmitter (cholinergic, dopaminergic and serotonergic) systems. This paper focuses on dopaminergic, cholinergic and histaminergic parameters in Alzheimer's disease (AD), Dementia with Lewy bodies (DLB) and Parkinson's disease (PD). In the normal striatum the dopamine transporter and D2 receptor exhibit distinct rostral-caudal distributions and D2 binding is affected by genetic polymorphism at the Taq 1A locus. The transporter is reduced in both DLB and $\mathrm{PD}$ but not $\mathrm{AD}$, correlating with severity of extrapyramidal dysfunction, and receptor abnormalities are apparent in DLB patients responding adversely to neuroleptics. Striatal nicotine receptors are lost in all 3 disorders, further reduced as a result of neuroleptic medication, and elevated as a result of tobacco use. In the thalamus there are selective reductions in presynaptic cholinergic activity in DLB in the reticular nucleus which relate to symptoms of hallucinations and fluctuating consciousness prevalent in this disorder. In the hippocampus coupling of muscarinic M1 receptors, relevant to response to cholinergic therapy, is impaired in areas most affected by $\beta$-amyloid plaques and intact in less affected areas. Analysis of histamine $\mathrm{H} 2$ receptors indicates that, despite presynaptic histamine abnormalities in $\mathrm{AD}$, receptor numbers are normal. Such clinically and therapeutically relevant observations on human brain neurochemistry provide a basis for im- 
proving therapeutic strategies and prospects of diagnostic in vivo chemical imaging.

Keywords: Alzheimer's disease, dementia with Lewy bodies, Parkinson's disease, dopamine transporter and receptors, choline acetyltransferase, nicotinic receptor, histamine $\mathrm{H} 2$ receptor.

\section{Introduction}

Research into the neurobiological basis of Alzheimer's disease (AD) has progressed dramatically across the last 2 or 3 decades from early observations on histopathological, metabolic and neurochemical abnormalities, to genetic and molecular pathological changes. Treatment strategies, by contrast, have evolved more slowly. The only pharmacologically available approach at present is cholinergic. Cholinesterase inhibitors such as Cognex (tacrine) or Aricept (donepezil) benefit a minority of AD patients (Rogers and Friedhoff, 1996). Recent evidence suggests that symptomatic improvement may relate more to psychotic features (e.g. hallucinations) than cognitive impairment. Patients with Dementia with Lewy bodies (DLB), in which Alzheimer pathology, (particularly neurofibrillary tangles) is less prevalent, may be more responsive (Perry et al., 1989; Levy et al., 1994; Cummings and Kaufer, 1996). Moreover there is some evidence that such therapy may additionally be protective (Davis et al., 1995), an observation consistent with the reduced risk of AD and PD (Parkinson's disease) in tobacco users (Court and Perry, 1994). Therapeutic expectations of anti-amyloidogenic strategies have yet to be realised although there is emerging evidence of the value of anti-inflammatory and antioxidant (vitamin E) agents. Transmitter manipulation is likely to remain an important target for symptomatic therapy in conjunction with some of these other protective approaches. Together with the application of new molecular probes for in vivo chemical imaging of transmitter systems, which has already identified cholinergic abnormalities in AD and PD (Kuhl et al., 1996), in vitro transmitter analysis in human brain tissue continues to be an exciting research area.

In a recent review of the functional consequences of transmitter complexity, Brezina and Weiss (1997) raised the question of how the functioning of the immensely complex network of transmitters, modulators, hormones and other chemical messengers can be analysed, particularly in view of the divergence in the action of a single transmitter (the range of different receptor subtypes for example) and the convergence of different transmitters (in terms of ion channel and second messenger modulation). At this level, there might seem to be little hope of deciphering the role of any particular molecular signal in contributing to behaviour, nor of targeting any particular clinical symptom by manipulating a single system. And yet major mental disorders and symptoms continue to be analysed mechanistically and manipulated pharmacologically in the context of specific systems. Examples include the role of dopamine and 5-HT receptors in psychosis, of 5-HT and noradrenaline transporters in depression, and most recently of acetylcholine in dementia. Possible relationships between the heterogeneity of genetic sequences coding for the relevant 
receptors, transporters or enzymes in various disease states are also being explored. A recent example in Alzheimer's disease is the reported synergy between the genes for butyrylcholinesterase $x$ variant and apolipoprotein E4 (Lehmann et al., 1997). Although therapeutic manipulations are largely considered in short term, symptomatic outcome, the evidence that chronic transmitter interactions influence not only membrane depolarisation but also gene transcription, indicates that transmitter signalling provides a basis for longer-term neurotrophic regulation.

This paper highlights some recent project areas currently being investigated by the Neurochemical Pathology group as part of Newcastle Brain Ageing and Dementia Research. These include: dopaminergic and cholinergic parameters in the striatum, being examined in relation to extrapyramidal disorder in DLB - recently identified as the second most prevalent form of dementia, after AD, in the elderly (McKeith et al., 1996); the role of the thalamus and its cholinergic activity in DLB and AD as these relate to attentional and REM (paradoxical) sleep abnormalities in these disorders; muscarinic cholinergic receptor coupling in AD, relevant to therapy and the evolution of $\beta$-amyloidosis; and histaminergic activity, which has been implicated in inflammatory reaction in AD.

\section{Striatal dopaminergic activities}

Binding to the dopamine uptake site is a presynaptic indicator of the number and activity of nigrostriatal dopaminergic neurons. Levels of binding are reduced in PD, correlating with cell loss in the substantia nigra and degree of extrapyramidal motor disability (Tatsch et al., 1997). In DLB extrapyramidal features are less prevalent and may be spontaneous or induced by dopamine antagonist medication administered for psychotic symptoms. Such reactions to antipsychotic (neuroleptic) medication can be severe, resulting in rigidity and premature death (McKeith et al., 1992). Substantia nigra neuron loss is less extensive than in $\mathrm{PD}$, as is the reduction in dopamine concentration in the striatum (Perry et al., 1990). In AD there is often mild movement disorder in the course of the disease. However, AD patients are usually tolerant of neuroleptics (McKeith et al., 1992). D2 receptors have been shown to be elevated in early and unmedicated PD (Antonini et al., 1995) and are reported to be higher with neuroleptic treatment in AD (Seeman et al., 1987).

Figure 1 illustrates the distributions of $\left[{ }^{3} \mathrm{H}\right]$ mazindol binding to the dopamine uptake site and of $\left[{ }^{3} \mathrm{H}\right]$ raclopride binding to the dopamine D2 receptor, assessed autoradiographically using published methodology (Joyce et al., 1988; Alexander et al., 1992), in a typical normal aged individual, at a coronal level just rostral of the anterior commisure. In a series of aged normals, dopamine uptake site density is highest in ventral caudate, showing an increasing gradient rosto-caudally (Fig. 2), while density was more uniform in the putamen.

D2 binding was more uniform dorso-ventrally across the striatum, while also displaying a rostro-caudal increasing gradient (Fig. 3). Amongst the variety of reported D2 receptor gene polymorphisms, we have recently 

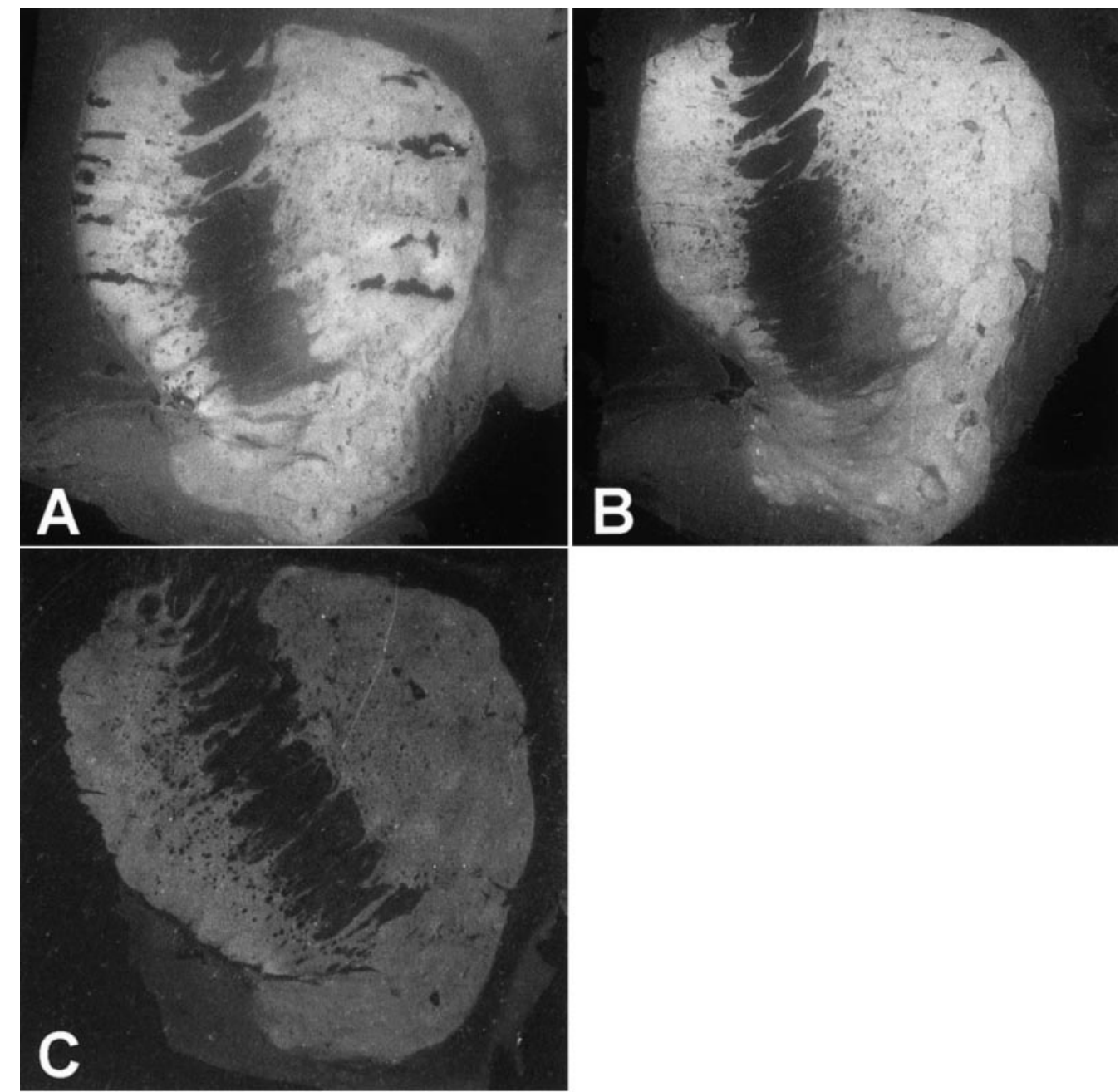

Fig. 1. Striatal distribution of a $\left[{ }^{3} \mathrm{H}\right]$ mazindol binding to dopamine uptake sites; $\mathbf{b}\left[{ }^{3} \mathrm{H}\right]$ raclopride binding to D2 receptors and $\mathbf{c}\left[{ }^{3} \mathrm{H}\right]$ nicotine binding to $\alpha_{4} \beta_{2}$ subtype nicotinic acetylcholine receptors, in a normal aged individual at a coronal level just rostral to the anterior commisure (level 12). Both dopamine uptake sites and D2 receptors tend to be localised to the matrix compartment of the striatum, while nicotine binding is patchy but does not apparently follow a striosome/matrix distribution

Fig. 2. Mazindol binding to dopamine uptake sites ( $\mathrm{fmol} / \mathrm{mg}$ tissue) in dorsal and ventral caudate and putamen in controls, DLB, PD and AD. Different coronal levels are $0.5 \mathrm{~cm}$ apart; level 9 marks the head of the caudate, level 10 the head of the putamen, level 11 the nucleus accumbens, level 12 the first appearance of the external globus pallidus, level 13 the anterior commisure and level 14 the internal globus pallidus. Histograms show average caudate and putamen binding in disease groups at rostral levels 10 and 11 only, and at more caudal levels $12-14$. PD cases are significantly reduced in rostral putamen, and both PD and DLB are significantly lower than controls in caudal caudate and putamen 

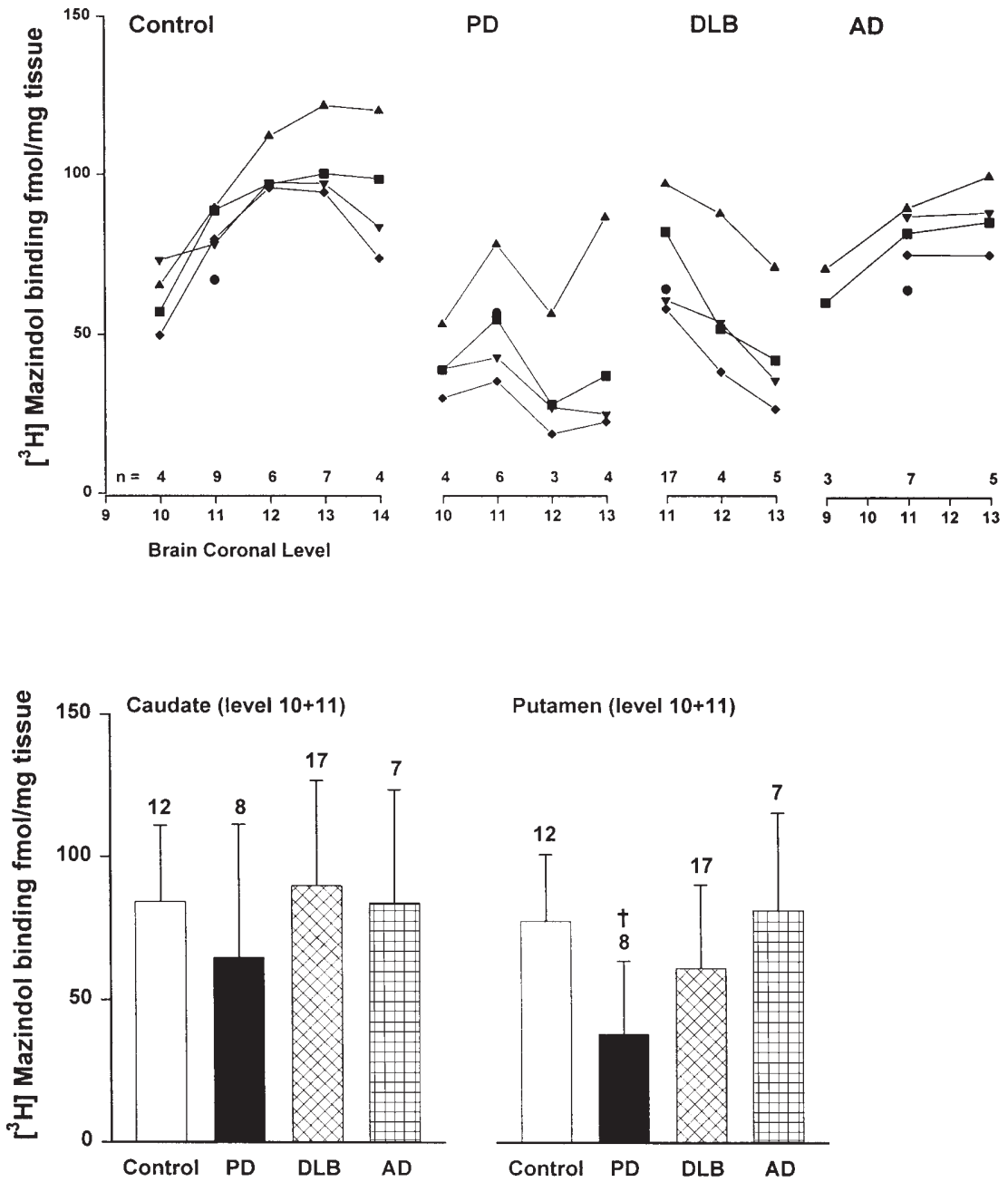

Putamen (level 10+11)
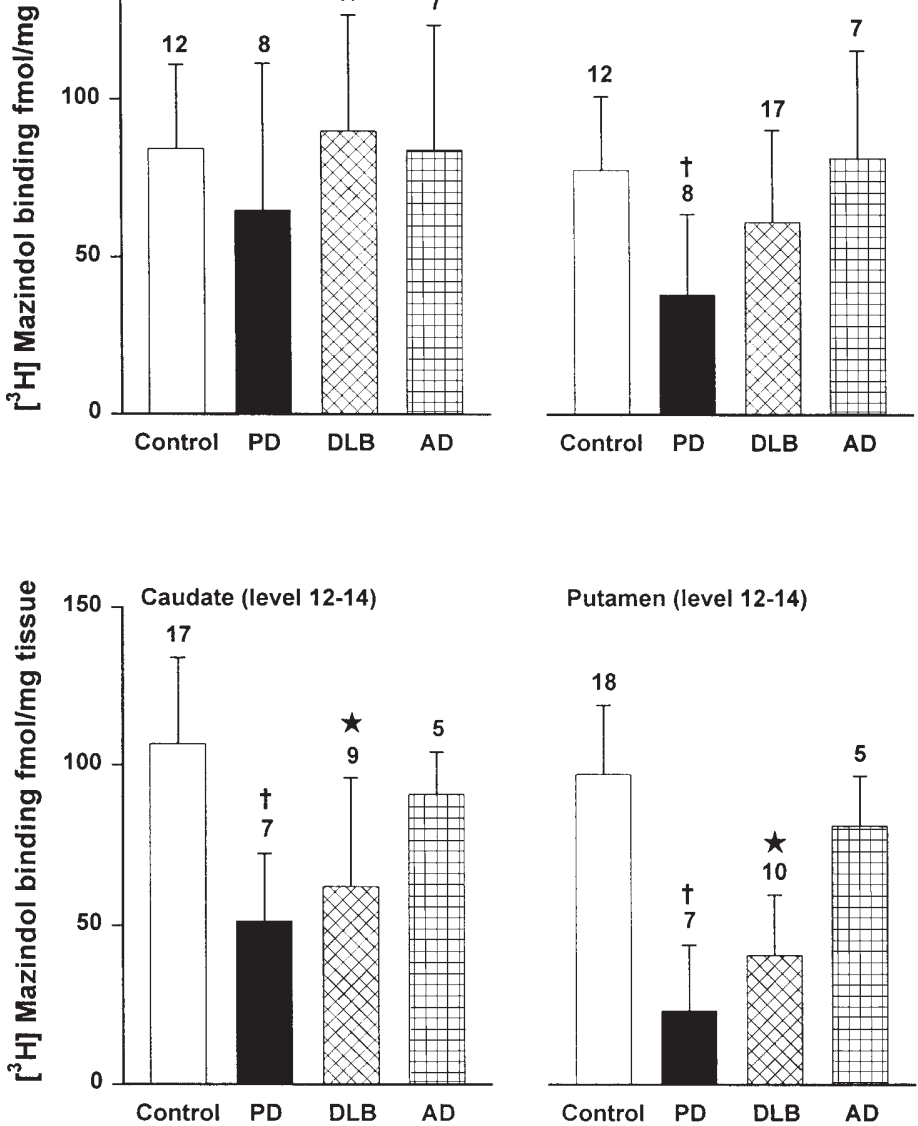

Putamen (level 12-14)

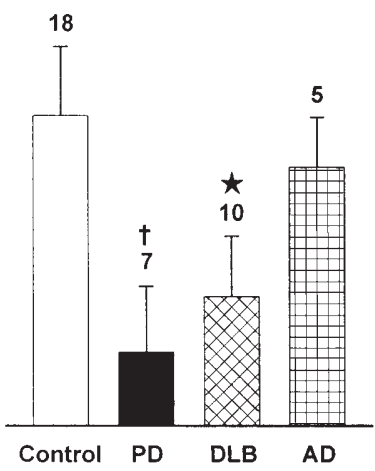



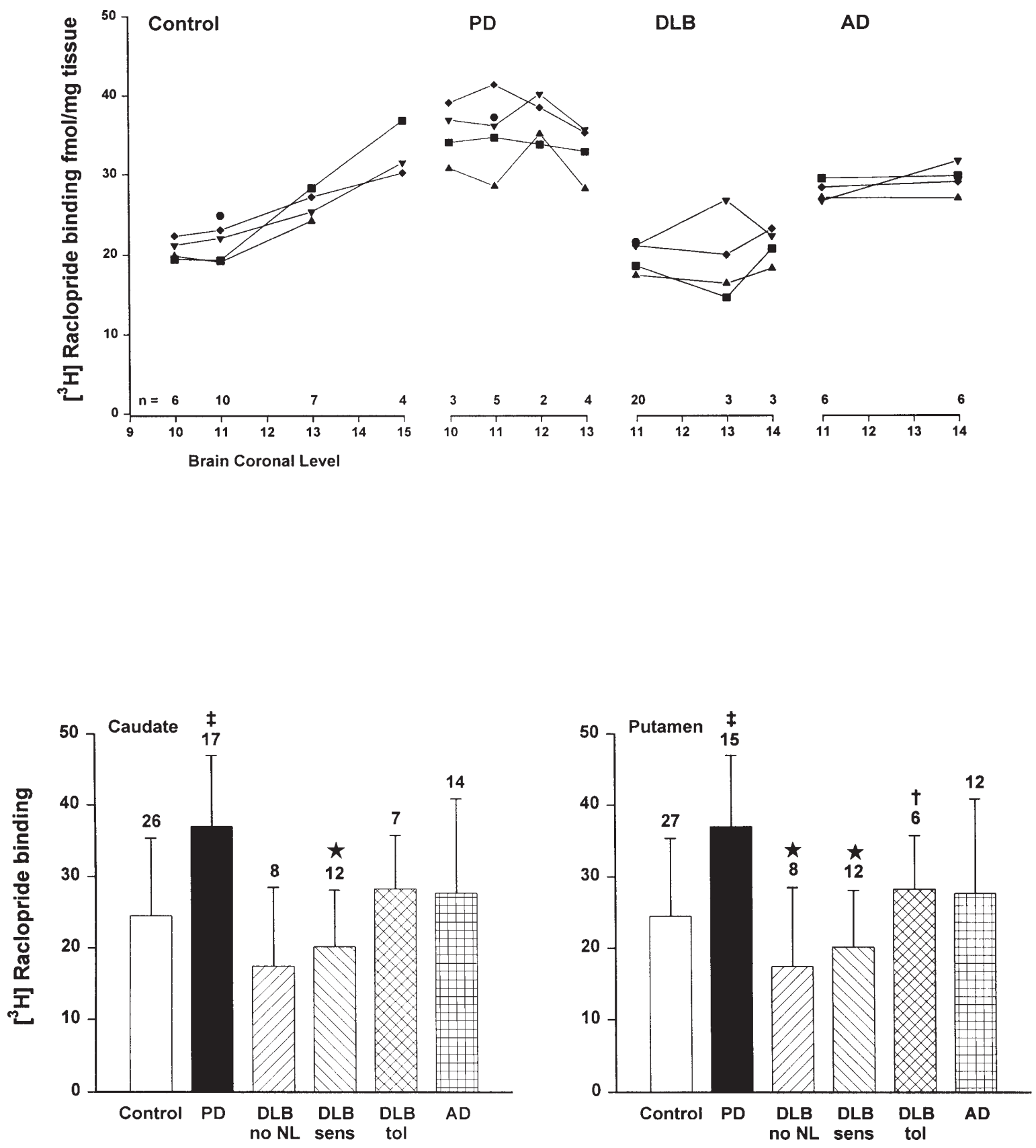

Fig. 3. $\left[{ }^{3} \mathrm{H}\right]$ Raclopride binding to dopamine $\mathrm{D} 2$ receptors (fmol/mg tissue) in dorsal and ventral caudate and putamen in controls, DLB, PD and AD at coronal levels as in Fig 2. Histograms show average caudate and putamen D2 binding at all levels distinguishing between DLB cases having no neuroleptic exposure, cases with severe sensitive reactions to neuroleptics, and cases tolerant of neuroleptics. Following general linear model analysis, which gave no significant interaction term between striatal area and disease group, dorsal and ventral caudate and putamen measures were collapsed and subjected to oneway ANOVA. PD cases had significantly higher D2 binding than all other groups in caudate and putamen ( $\$)$. The neuroleptic sensitive DLB group had lower D2 binding than AD cases and controls in caudate and putamen (*), as did neuroleptic naïve and sensitive cases had lower binding than neuroleptic tolerant cases in the putamen $(\dagger)$ 
identified a correlation between Taq 1 A1 and A2 allele frequency (Grandy et al., 1989) and the density of striatal D2 receptor binding in a series of 42 elderly normal individuals (Thompson et al., 1997). Binding was higher in A2 homozygotes compared to A1/A2 heterozygotes particularly in ventral striatum. The difference was more prominent in males compared to females and in ventral putamen there was over 2 fold higher binding in males with A2/ A2 compared with A1/A2 genotype. The clinical correlate of these genetically linked variations has not yet been established although the importance of ventral striatal dopaminergic activity in relation to reinforcement/reward mechanisms and mood (Parent, 1990) raises the question of whether there are disease related genetic variations associated with apathy or depression, common features of degenerative diseases such as PD and DLB which affect the basal ganglia.

Comparisons of dopamine D2 receptor and uptake sites were made in a series of cases of Parkinson's disease (PD), Dementia with Lewy bodies (DLB) and Alzheimer's diseases (AD), meeting previously described clinical and pathological criteria (Perry R et al., 1990). In PD dopamine uptake sites were significantly reduced in the putamen compared to controls at all coronal levels, in dorsal caudate at levels 11 to 14 , and in ventral caudate at level 12 (see legends to Fig. 1 and 2 for localization of levels). In DLB dopamine uptake site losses were less extensive, especially rostrally, being significantly less than controls only in dorsal putamen at levels 11 to 13 , and in ventral putamen and dorsal caudate at level 13. In AD there was no loss of dopamine uptake sites, except for a tendency for lower levels caudally in the putamen.

In PD there was elevated D2 binding compared to controls in both caudate and putamen at all levels, with the greatest elevation rostrally and least increase in posterior caudate. By contrast in DLB D2 receptors were not elevated (tending to be lower than controls) even at caudal levels where reduced dopamine uptake site binding was seen, suggesting that the loss of dopamine innervation fails to invoke D2 upregulation in this disease. In AD there was no change from control D2 binding, except for a trend towards increased binding in those cases which had been exposed to neuroleptics.

Examining DLB cases according to neuroleptic exposure and sensitivity (Fig. 3), it was apparent that in the drug sensitive group D2 receptors failed to upregulate in response to neuroleptic administration. The group which tolerated neuroleptic medication showed upregulated D2 receptors compared to the drug naïve group. The mechanism of drug intolerance in neuroleptic sensitive DLB thus involves an inability to modulate D2 receptor numbers.

\section{Nicotine binding in the striatum: effects of neurodegenerative disease, neuroleptic medication and cigarette smoking}

A subset of nicotinic acetylcholine receptors, binding such agonists as nicotine with high affinity and reflecting predominantly $\alpha_{4}$ and $\beta_{2}$ subunits (Lindstrom et al., 1996) has been shown to be reduced in neurodegenerative diseases such as Alzheimer's disease (AD), Parkinson's disease (PD) and Dementia with 
Lewy bodies (DLB) from brain areas that are particularly associated with neuropathology. For example in AD nicotine binding in the parahippocampal gyrus is more affected than in DLB, and in PD and DLB nicotine binding is lost from the substantia nigra ( $\mathrm{SN}$ ) pars compacta to an equal degree, although loss of SN neurons is greater in PD (Perry et al., 1995). In normal ageing, nicotine binding is lost from the frontal cortex, although there is no change in the presynaptic cholinergic marker choline acetyltransferase (Court et al., 1997). These data suggest that reduction in high affinity nicotine binding occurs at a relatively early stage of neurodegeneration and may be linked with the failure of cell survival.

In the present study high affinity nicotine binding was measured, using methodology previously described (Court et al., 1997), in the caudate nucleus and putamen and compared in patients demonstrating basal ganglia pathology (PD and DLB) with patient groups not generally associated with dopaminergic hypofunction (AD) and schizophrenia (SZ). Figure 1 shows ${ }^{3} \mathrm{H}$ nicotine binding distribution in the striatum. Since many individuals with SZ smoke tobacco and together with some patients with dementia are prescribed neuroleptic medication, these factors were also taken into account in the analysis.

In patients with $\mathrm{PD}$ and DLB, high affinity receptor binding was reduced in the caudate and the putamen (Table 1), consistent with the presence of this receptor on dopamine terminals, as indicated by studies in vitro in rodents (Grady et al., 1994; Harsing et al., 1992; Rowell, 1995). Nicotine binding was also reduced in the striatum in AD compared to controls, but not to the same extent as in DLB or PD, particularly in the putamen (Table 1). This may reflect modest basal ganglia pathology in AD, most notable in striatal association rather than motor areas.

Most interesting was the finding that neuroleptic medication was associated with further reductions in striatal high affinity nicotine binding in DLB and to a lesser extent in $\mathrm{AD}$ (Table 1), possibly indicating that persistent

Table 1. Nicotine binding in the striatum: effects of disease, neuroleptic medication and tobacco smoking

\begin{tabular}{|c|c|c|c|c|c|c|c|c|c|}
\hline & \multicolumn{3}{|c|}{ Controls } & \multicolumn{2}{|l|}{$\mathrm{AD}$} & \multicolumn{2}{|l|}{ DLB } & \multirow{2}{*}{$\frac{P D}{(13)}$} & \multirow{2}{*}{$\frac{S Z}{(6)}$} \\
\hline & $\begin{array}{l}\text { All } \\
(41)\end{array}$ & $\begin{array}{l}\text { Non-smokers } \\
\text { (10) }\end{array}$ & $\begin{array}{l}\text { Smokers } \\
(7)\end{array}$ & $\begin{array}{l}\text { no NL } \\
(5)\end{array}$ & $\begin{array}{l}\text { plus NL } \\
\text { (8) }\end{array}$ & $\begin{array}{l}\text { no NL } \\
(8)\end{array}$ & $\begin{array}{l}\text { plus NL } \\
\text { (14) }\end{array}$ & & \\
\hline Average caudate & $\begin{array}{c}8.67 \\
\pm \\
\end{array}$ & $\begin{array}{l}8.28 \\
\pm \\
20\end{array}$ & $\begin{array}{c}11.16 \\
\pm\end{array}$ & $\begin{array}{c}5.98 \\
\pm \\
106+\end{array}$ & $\begin{array}{c}4.92 \\
\pm \\
\end{array}$ & $\begin{array}{r}6.30 \\
\pm \\
\end{array}$ & $\begin{array}{l}3.21 \\
\pm \\
\pm 3\end{array}$ & $\begin{array}{c}4.52 \\
\pm \\
57\end{array}$ & $\begin{array}{c}13.97 \\
\pm \\
570 \pm\end{array}$ \\
\hline Average putamen & $\begin{array}{c}5.02 \\
8.13 \\
\pm \\
3.15\end{array}$ & $\begin{array}{l}7.19 \\
\pm \\
1.94\end{array}$ & $\begin{array}{c}11.09 \\
\pm \\
3.20\end{array}$ & $\begin{array}{c}1.90 \pi \\
6.42 \\
\pm \\
1.44\end{array}$ & $\begin{array}{c}1.55 x \\
5.40 \\
\pm \\
1.94 \star\end{array}$ & $\begin{array}{c}2.04 \pi \\
4.43 \\
\pm \\
0.85 \star\end{array}$ & $\begin{array}{l}2.92 \\
\pm \\
1.54\end{array}$ & $\begin{array}{c}3.30 \\
\pm \\
1.98 \star\end{array}$ & $\begin{array}{c}15.43 \\
\pm \\
7.34 \star\end{array}$ \\
\hline
\end{tabular}

$\star$ Significantly different from controls (All). Control smokers significantly higher than non-smokers. - DLB with NL significantly different from DLB without neuroleptics. SZ (schizophrenic patients) not significantly different from smoking controls 
blockade of dopamine D2 receptors by neuroleptics may lead to an increased degeneration of nigro-striatal dopaminergic terminals. This may be particularly important when these neurons are already significantly compromised as in DLB. By contrast, in SZ, in which high doses of neuroleptics are prescribed, an increase rather than a loss of nicotine binding was observed. This increase probably reflects the high prevalence of tobacco smoking in these patients (McEvoy and Lindgren, 1996), since smoking in the control group was associated with increased striatal levels of nicotine binding (Table 1). Although the mean values of striatal nicotine binding in $\mathrm{SZ}$ appeared higher than in control cases who were known to have smoked tobacco, they were not significantly altered.

These findings highlight the complexity of neurodegenerative changes in diseases of the elderly, in particular the effects of drug/disease interaction on neurochemical parameters.

\section{Cholinergic activities in the thalamus}

The thalamus has not been a focus for much pathological or neurochemical research in $\mathrm{AD}$. Yet, in terms of cholinergic anatomy, it receives $85-95 \%$ of its input from the brainstem as cholinergic projections originating from the pedunculopontine and lateral dorsal tegmental cholinergic nuclei in the brainstem (Bentovoglio and Steriade, 1990). Select thalamic nuclei, particularly reticular and mediodorsal also receive cholinergic projections from basal forebrain cholinergic neurons (Brandel et al., 1990; Heckers et al., 1992). Cholinergic transmission in the thalamus involves excitation via early nicotine and slower muscarinic receptor activated depolarisation, and also via indirect hyperpolarisation of GABAergic reticular thalamic cells (McCormick and Prince, 1987; Hu et al., 1989). Co-activtion of brainstem and forebrain cholinergic neurons is thought to critically control cortical activation occurring in both wakefulness and REM (paradoxical) sleep. Cholinergic activities in the thalamus are thus of interest in diseases involving cholinergic pathology and treatment with cholinergic drugs.

Figure 4 compares the distribution in normal human thalamus of acetylcholinesterase (which is in most nuclei an index of cholinergic input paralleling the distribution of choline acetyltransferase, Heckers et al., 1992) with ${ }^{3} \mathrm{H}$-nicotine and ${ }^{125} \mathrm{I}-\alpha$-bungarotoxin binding (which reflect receptor subtypes thought to consist primarily of $\alpha_{4} \beta_{2}$, and $\alpha_{7}$ respectively (Albuquerque et al., 1996; Lindstrom et al., 1996). The methodology for nicotinic receptor autoradiography in frozen human brain cryostat sections and for choline acetyltransferase in discrete samples from adjacent sections containing the different nuclei is described in detail elsewhere (Spurden et al., 1997).

A comparison of age and post mortem delay matched groups of normal elderly individuals and cases of $\mathrm{AD}$ and DLB, meeting clinical and neuropathological criteria (Mirra et al., 1991; McKeith et al., 1996) is provided in Table 2. Although trends towards reduced presynaptic cholinergic activity (choline acetyltransferase) were apparent in all the nuclei examined in both $\mathrm{AD}$ and $\mathrm{DLB}$, the only significant reduction was in the reticular nucleus in 


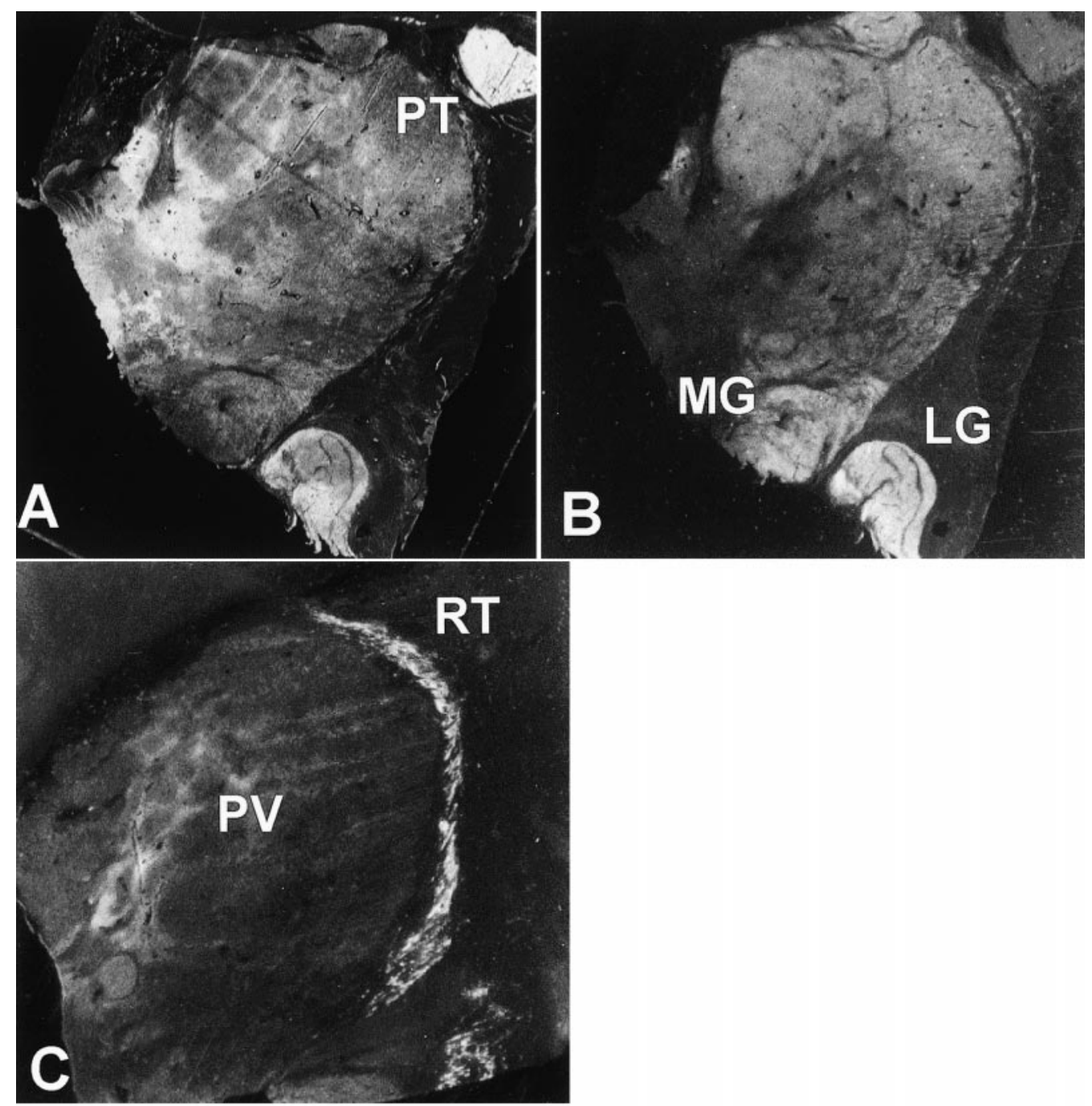

Fig. 4. Distribution of acetylcholinesterase staining (a), $\left[{ }^{3} \mathrm{H}\right]$ nicotine binding $(\mathbf{b})$, and ${ }^{125} \mathrm{I}-$ $\alpha$-bungarotoxin binding (c) in sections of normal posterior human thalamus. $C N$ caudate nucleus; $L G$ lateral geniculate nucleus; $L P$ lateral posterior; $M D$ medial dorsal; $M G$ medial geniculate; $P V$ pulvinar; $R$ reticular. Magnification $\times 1.5(\mathrm{a}, \mathrm{b}), \times 2.0(\mathrm{c})$

DLB. In DLB and AD patients with as opposed to without hallucinations, enzyme activities in the reticular nucleus were respectively $7.3 \pm 3.7(\mathrm{n}=15)$ compared to $15.3 \pm 19.0(\mathrm{n}=5) \mathrm{nmol} / \mathrm{h} / \mathrm{mg}$ protein, a trend which is similar to that found, significantly, in the neocortex (Perry et al., 1990; Perry and Perry, 1995). There was a similar trend between individuals with and without fluctuating consciousness $(6.0 \pm 3.8(\mathrm{n}=8)$ versus $14.4 \pm 15(\mathrm{n}=7))$ which is another distinguishing clinical feature of DLB.

${ }^{3} \mathrm{H}$ nicotine binding was not substantially altered in the thalamic nucleus although moderate reductions in DLB and AD reached significance in the anterior nucleus where binding was (together with lateral and medial geniculate nuclei) concentrated (Fig. 4, Table 2). For $\alpha$-bungarotoxin, the 
Table 2. Presynaptic cholinergic activity and nicotinic receptor binding in the human thalamus

\begin{tabular}{|c|c|c|c|}
\hline Nucleus & Control & DLB & $\mathrm{AD}$ \\
\hline \multicolumn{4}{|c|}{ Choline acetyltransferase (nmol/h/mg protein) } \\
\hline Anterior & $14.0 \pm 11.2(12)$ & $16.4 \pm 8.5(11)$ & $6.8 \pm 2.9(9)$ \\
\hline Lateral geniculate & $16.7 \pm 20.3(7)$ & $7.7 \pm 7.6(7)$ & $10.2 \pm 6.7(7)$ \\
\hline Reticular & $14.4 \pm 10.4(15)$ & $\star 7.1 \pm 4.2(13)$ & $11.1 \pm 12.8(11)$ \\
\hline \multicolumn{4}{|l|}{ Nicotine binding (fmol/mg) } \\
\hline Anterior & $30.4 \pm 8.3(10)$ & $\star 24.5 \pm 5.7(14)$ & $\star 23.4 \pm 5.2(13)$ \\
\hline Lateral geniculate & $31.7 \pm 5.2(8)$ & $26.3 \pm 6.1(6)$ & $26.2 \pm 5.9(6)$ \\
\hline Reticular & $12.1 \pm 3.9(15)$ & $11.4 \pm 3.4(14)$ & $12.2 \pm 3.9(12)$ \\
\hline \multicolumn{4}{|c|}{$\alpha$-Bungarotoxin binding (fmol/mg) } \\
\hline Anterior & $1.3 \pm 0.9(7)$ & $1.0 \pm 0.6(14)$ & $1.3 \pm 1.4(12)$ \\
\hline Lateral geniculate & $2.2 \pm 1.2(5)$ & $3.0 \pm 1.3(9)$ & $2.3 \pm 1.5(9)$ \\
\hline Reticular (dense zones) & $13.6 \pm 3.8(12)$ & $\star 7.6 \pm 3.4(16)$ & $\star 7.4 \pm 3.5(13)$ \\
\hline
\end{tabular}

$\star$ Significantly below controls $(\mathrm{p}<0.05)$

pattern of binding was totally different with only the reticular nucleus demonstrating high specific binding (Fig. 4). Binding was significantly reduced in both AD and DLB (Table 2), particularly from the localised dense areas which correspond to the individual acetylcholinesterase positive neurons in the nucleus (Spurden et al., 1997). The only clinical correlate of this abnormality so far identified is a significant inverse correlation in patients with AD and DLB with repeated falls (Spurden et al., in preparation).

These observations are consistent with a previous report that thalamic cholinergic activity is not significantly altered in AD (Xuereb et al., 1991). The new finding that activity is diminished in DLB in the reticular nucleus is likely to be important in relation to the symptoms specific to DLB such as hallucinations and fluctuating attention or consciousness. Since cholinergic activity is critically involved in REM sleep (Hobson et al., 1986; Hobson, 1992) it will be of interest to relate thalamic cholinergic deficits to REM abnormalities including REM behavioural disorder (RBD) recently reported in DLB (Uchiyama et al., 1995; Turner et al., 1997). RBD involves motor activation during dreaming and is prevalent in PD (Schenck et al., 1996). In terms of therapy, since current cholinergic drugs are not targeted to specific brain areas they are likely to affect thalamic activities as much as cortical and, particularly in DLB, this may be relevant to therapeutic outcome.

The absence of marked reductions in nicotine binding in the thalamus in $\mathrm{AD}$ and DLB contrasts with findings in the cortex (reviewed Court and Perry, 1994) and suggests the majority of binding is associated less with presynaptic cholinergic than other components of thalamic circuitry. The loss of $\alpha \mathrm{BT}$ binding is the first identification of an involvement of this receptor in degenerative dementia although the receptor has been implicated in schizophrenia (Freedman et al., 1995; Leonard et al., 1996). 


\section{Muscarinic receptor coupling}

It has been known since 1987 (Smith et al., 1987; Warpman et al., 1993; Ogawa et al., 1993; Ladner et al., 1995) that there are alterations in muscarinic receptor coupling in the cortex in AD. M1 uncoupling is likely to reflect pathological changes in postsynaptic cholinoceptive neurons, such as the occurrence of neurofibrillary tangles. With more recent evidence that M1 receptor activation facilitates the normal secretase pathway of amyloid precursor protein metabolism (Nitsch and Growdon, 1994), it has been postulated that the abnormal deposition of $\mathrm{A} \beta$ in $\mathrm{AD}$ may reflect hypocholinergic activity. Although the chronological sequence of defects in cholinergic transmission and $\beta$-amyloid deposition is not yet clear, there is no doubt that if M1 receptors are irreversibly uncoupled this will compromise the efficacy of cholinergic therapy.

Receptor coupling was further investigated autoradiographically in the hippocampus in relation to severity of $\beta$-amyloidosis. Comparisons between normal and AD were made, based on the effects of the GTP analogue, $\mathrm{GPP}(\mathrm{NH}) \mathrm{P}$ on carbachol displacement of pirenzepine binding, according to the protocol of Smith et al. (1987). This permitted examination of coupling defects at the topographical level in relation to the deposition of $\beta$-amyloid plaques, detected immunohistochemically using an antibody to $\mathrm{A} \beta$ (Dako). Figure 5 illustrates the distribution of ${ }^{3} \mathrm{H}$ pirenzepine in normal hippocampus and adjacent cortex and its displacement of carbachol in the presence and absence of $100 \mu \mathrm{M}$ GPP(NH)P. Figure 6 compares the extent of coupling in control and AD cases and demonstrates that impaired coupling is evident more in areas affected by higher plaque densities, including eg entorhinal cortex than those with few plaques eg CA4. A complicating factor in this analysis is the occurrence of smaller numbers of plaques in some of these areas in the elderly control cases and it would be of interest to examine coupling in younger compared to older normal individuals. There is a loss of cholinergic activity with age in both hippocampus and entorhinal cortex (Perry et al., 1992). It is worth noting that in hippocampal sub-regions such as CA4 and CA2/3 endplate, where the hippocampal cholinergic input is most concentrated, there is no impairment in coupling. In these areas enhancing cholinergic transmission in AD will presumably still be therapeutically effective.

\section{Histaminergic transmission}

In addition to the well documented changes in the cholinergic and monoaminergic systems, degeneration of the neuronal histamine system has been demonstrated in AD and is being investigated in other disorders.

Histamine synthesising neurones are located solely in the tuberomammillary nucleus (TMN) of the posterior hypothalamus and can be identified immunocytochemically using antibodies either to histamine or its synthesising enzyme histidine decarboxylase (HDC). In human around 64,000 neurones in and around the TMN are immuno-reactive for histamine, a similar number to that of noradrenergic neurones found in the locus coeruleus (Airaksinen et al., 1991). 

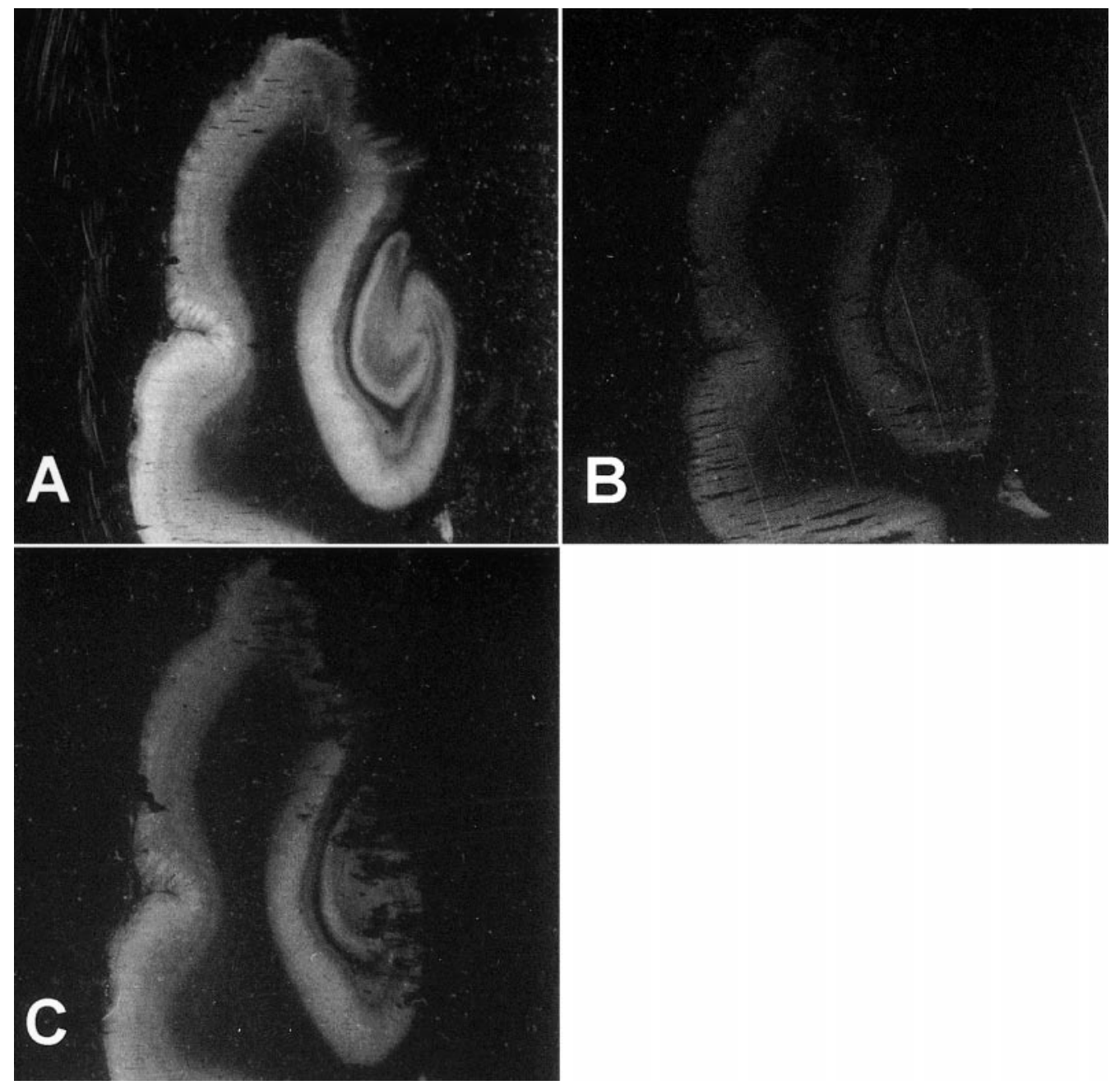

Fig. 5. $\left[{ }^{3} \mathrm{H}\right]$-Pirenzepine binding to the muscarinic cholinergic receptor $\mathrm{M} 1$ in the normal hippocampus and adjacent parahippocampal gyrus or entorhinal cortex. Receptor coupling is measured as the difference between carbachol displaced binding in the presence

(uncoupled state) and absence (coupled state) of the GTP analogue, GPP(NH)P

Histamine-immunoreactive fibres have been found in various brain areas in primate and human. Human studies have been limited so far, but histaminergic innervation has been found in many regions and HDC activity has been detected throughout the brain (Barbin et al., 1980). The histamine system is unusual in showing a remarkably homogeneous distribution; aside from the posterior hypothalamus, HDC levels are very similar across many brain areas. In the macaque monkey, where the system has been traced in finer detail than human, fibres show little regard for anatomical divisions with individual fibres with many varicosities running straight through adjacent, unrelated, brain nuclei (Manning et al., 1996).

A number of studies on human tissue have shown changes in the histaminergic system in AD. In the hypothalamus of AD cases numerous neurofibrillary tangles were concentrated in the TMN (Airaksinen et al., 1991), and these 

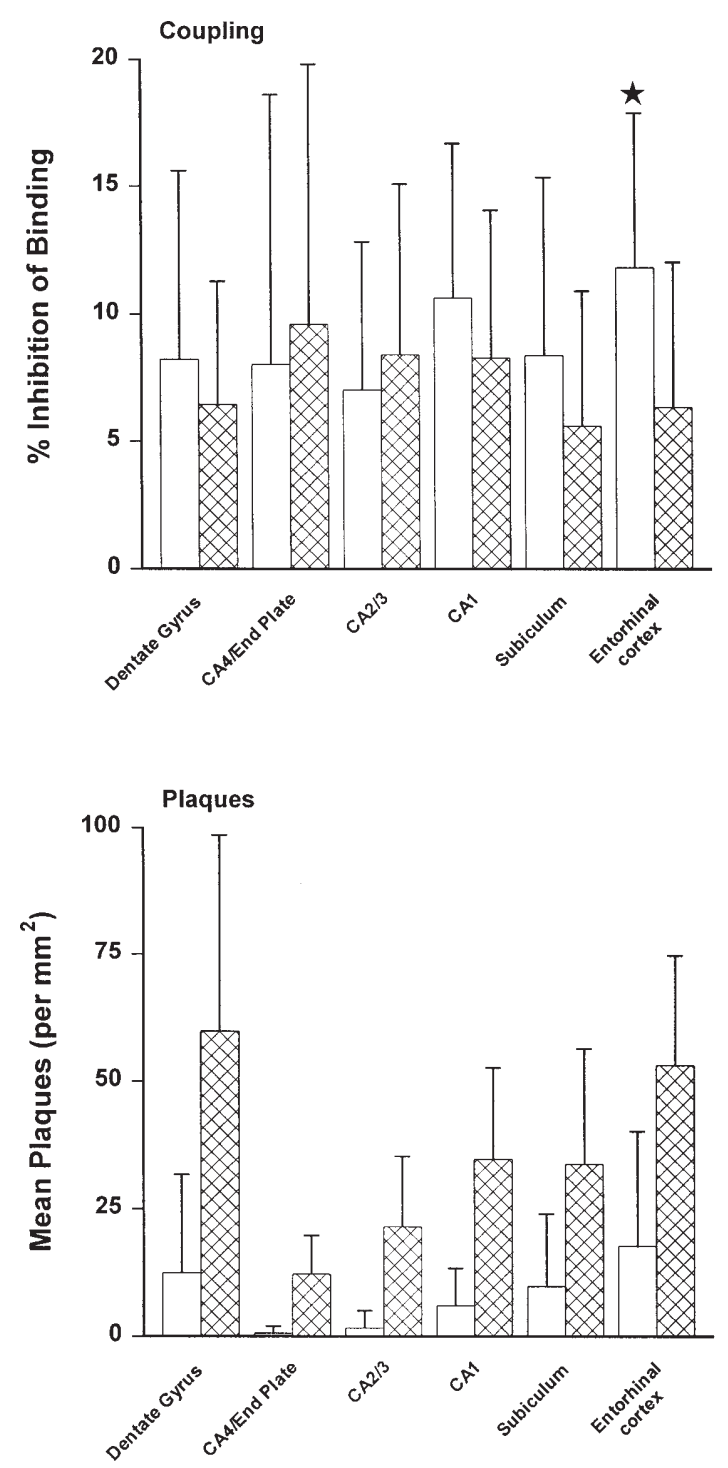

Fig. 6. Muscarinic M1 receptor coupling measured in different regions of the hippocampus and adjacent cortex (see also Fig. 5) and the density of A $\beta$ reactive plaque in the same regions assessed immunocytochemically. Differences between the normal (unhatched columns) and cases of Alzheimer's disease (hatched columns) were significant for all areas with respect to plaques but only entorhinal cortex with respect to reduced coupling. Columns are mean values and bars standard deviations in 14 control and 13

Alzheimer cases

appear to be associated with neurodegeneration since the number of large neurones in this area has also been found to be decreased (Nakamura et al., 1993). Consistent with these observations reduced levels HDC activity have been found in the frontal cortex of AD brains (Schneider et al., 1997).

To study further the histaminergic system in Alzheimer's disease the density of $\mathrm{H} 2$ receptors was investigated in several brain areas. Receptor 


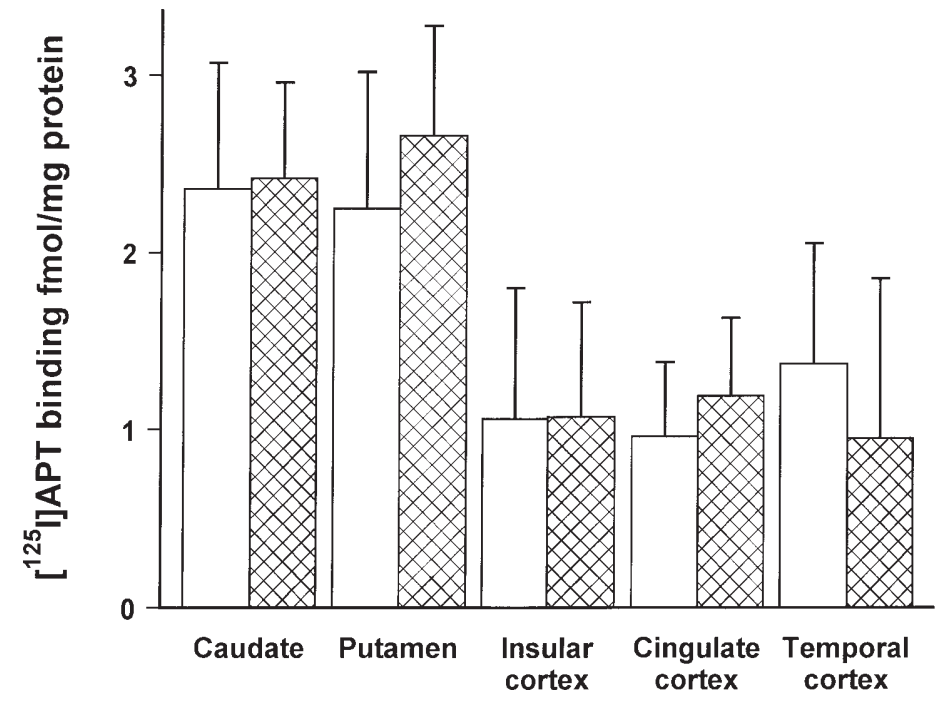

Fig. 7. Histamine $\mathrm{H} 2$ binding, measured using [ $\left.{ }^{125} \mathrm{I}\right]$-APT, in striatal and cortical regions from a control group (unhatched bars, 6-10 cases) and group of cases with Alzheimer's disease (hatched bars, 4-9 cases)

numbers were measured using the specific H2-receptor antagonist [125I]iodoaminopotentidine ([125I]-APT) as described by Traiffort et al. (1992).

No significant differences were found between the AD and control group in any region examined (Fig. 7). It is perhaps unsurprising that no change in the striatum, a region relatively spared in AD was observed. However it is notable that receptors were also unchanged in all cortical areas examined despite these, the temporal cortex in particular, being areas of more dense Alzheimer-type pathology. There was also no significant correlation between binding density in any area and either age, post-mortem delay or gender.

This study was initiated by an epidemiological study suggesting reduced risk of $\mathrm{AD}$ with $\mathrm{H} 2$ receptor antagonist use (Breitner et al., 1995). This has since been contradicted by a more recent study (Launer et al., 1997), which together with our inability to find any changes in receptor density, suggests no irregularities in $\mathrm{H} 2$ receptors in $\mathrm{AD}$. It will be interesting to carry out a study looking at the histamine $\mathrm{H} 1$ receptor, which is found at its highest densities in the cortex (Martinez-Mir et al., 1990).

\section{Concluding remarks}

This paper summarises some of the ways in which investigations of neurochemical pathology in the human brain can contribute to current research in aging and dementia. Examination of phenotypic expression in terms of stable, quantifiable transmitter related receptor and enzyme activities provides in conjunction with clinical, pathological, genetic and pharmacological data, new insights into biological mechanisms relevant to treatment and diagnosis. Immunocytochemical and mRNA analysis provide similar opportunities although immunoreactivity is less readily quantifiable and many mRNA species 
are affected by non-specific pre or post mortem variables. While brain banking is costly, in terms of resources and some of the techniques are labour intensive, neurochemical pathology continues to be an invaluable component of interdisciplinary research programmes.

The complexity of neurotransmitter actions and interactions was highlighted at the beginning of this article as a major challenge to unravelling the function and therapeutic relevance of specific systems in disorders of the human brain. To this must be added the equal challenge of determining meaningful clinical correlates of phenotypic changes in different diseases, given increasing numbers of influential factors which may or may not be disease related. These include, as exemplified in this paper, specific genotypic variations, gender, medication and recreational substance use. No doubt these are only a few of many environmental and social factors that remain to be identified. When disease related neurochemical pathology does emerge as consistently reported and substantial abnormalities in relatively small groups it is likely to be important. Given that such pathology involves different transmitter pathways in degenerative dementias such as AD, DLB and PD, to a greater or lesser extent in different individuals within each group, an important target for future research will be to identify neurochemical correlates of clinical response to emerging pharmacological treatments. Until preventative strategies become a reality, symptomatic treatment in patients presenting with these disorders will be required and transmitter targeted therapy may also be neuroprotective.

\section{Acknowledgements}

The authors are grateful to D. Houghton and L. Hood for manuscript preparation and to the Medical Research Council and British American Tobacco for financial support.

\section{References}

Airaksinen MS, Paetau A, Paljarvi L, Reinikainen K, Riekkinen P, Suomalainen R, Panula P (1991) Histamine neurons in human hypothalamus: anatomy in normal and Alzheimer's diseased brains. Neuroscience 44: 465-481

Albuquerque EX, Pereira EFR, Bonfante-Carbarcas R, Marchioro M, Matsubayashi H, Alkondon M, Maelicke A (1996) Nicotinic acetylcholine receptors on hippocampal neurons: cell compartment - specific expression and modulatory control of channel activity. Prog Brain Res 109: 111-124

Alexander GM, Schwartzman RJ, Brainard L, Gordon SW, Grothusen (1992) Changes in brain catecholamines and dopamine uptake sites at different stages of MPTP parkinsonism in monkeys. Brain Res 588 (2): 261-269

Antonini A, Vontobel P, Psylla M, Gunther I, Maguire PR, Missimer J, Leenders KL (1995) Complementary positron emission tomographic studies of the striatal dopaminergic system in Parkinson's disease. Arch Neurol 52: 1183-1190

Bentivoglio M, Steriade M (1990) Brainstem diencephalic circuits as a structural substrate of the ascending reticular activation concept. In: Marcia M, Marini G (eds) The diencephalon and sleep. Raven Press, New York, pp 7-29

Barbin G, Palacios JM, Garbarg M, Schwartz JC, Gaspar P, Javoy-Agid F, Agid Y (1980) L-Histidine decarboxylase in the human brain: properties and localization. $J$ Neurochem 35: 400-406 
Brandel JPA, Hirsch EC, Hersh LB, Javoy-Agid F (1990) Compartmental ordering of cholinergic innervation of the mediodorsal mucleus of the thalamus in human brain. Brain Res 515: 117-125

Breitner JC, Welsh KA, Helms MJ, Gaskell PC, Gau BA, Roses AD, Pericak-Vance MA, Saunders AM (1995) Delayed onset of Alzheimer's disease with nonsteroidal anti-inflammatory and histatamine $\mathrm{H} 2$ blocking drugs. Neurobiol Aging 16: 523-530

Brezina V, Weiss KR (1997) Analysing the functional consequences of transmitter complexity. Trends Neurosci 20: 538-543

Court JA, Perry EK (1994) CNS nicotinic receptors: therapeutic target in neurodegeneration. CNS Drugs 2: 216-233

Court JA, Piggott MA, Perry EK, Barlow RB, Perry RH (1992) Age associated decline in high affinity nicotine binding in human brain frontal cortex does not correlate with the changes in choline acetyltransferase activity. Neurosci Res Commun 10: 125-133

Court JA, Lloyd S, Johnson M, Griffiths M, Birdsall NJM, Piggott MA, Oakley AE, Ince PG, Scott DJ, Perry EK, Perry RH (1997) Nicotinic and muscarinic cholinergic receptor binding in the human hippocampal formation during development and aging. Dev Brain Res 101: 93-105

Cummings YL, Kaufer D (1996) Neuropsychiatric aspects of Alzheimer's disease: the cholinergic hypothesis revisited. Neurology 47: 876-883

Davis RE, Doyle PD, Carroll RT, Emmerling MR, Jaen J (1995) Cholinergic therapies for Alzheimer's disease - paliative or disease altering? Arzneimittelforschung 45: 425-431

Freedman R, Conn H, Myles-Worsley M, Orr-Urteger A, Olincy A, Davis A, Polymeropoulos M, Holik J, Hopkin J, Rosenthal J, Waldo MC, Reimherr F, Wender P, Yaw J, Young DA, Breese CR, Adams C, Patterson D, Adler LE, Kruglyak L, Leonard S, Byerley W (1997) Linkage of a neurophysiological deficit in schizophrenia to a chromosome 15 locus. Proc Natl Acad Sci USA 94: 587-592

Grady SR, Marks MJ, Collins AC (1994) Desensitisation of nicotine-stimulated $\left[{ }^{3} \mathrm{H}\right]$ Dopamine release from mouse striatal synaptosomes. J Neurochem 62: 13901398

Grandy DK, Litt M, Allen L, Bunzow JR, Marchionni M, Makam H, Reed L, Magenis $\mathrm{RE}$, Civelli O (1989) The human doamine D2 receptor gene is located on chromosome 11 at q22-q23 and identifies a TaqI, RFLP. Am J Hum Genet 45: 778-785

Harsing LG, Sershen H, Lajtha A (1992) Dopamine efflux from striatum after chronic nicotine: evidence for autoreceptor desensitisation. J Neurochem 59: 48-54

Heckers S, Geula C, Mesulam MM (1992) Cholinergic innervation of the human thalamus: dual origin and differential nuclear distribution. J Comp Neurol 325: 68-82

Hobson JA (1992) Sleep and dreaming: induction and mediation of REM sleep by cholinergic mechanisms. Curr Opin Neurobiol 2: 759-763

Hobson JA, Lydic R, Baghdoyan HA (1986) Evolving concepts of sleep cycle generation - from brain centres to neuronal populations. Behav Brain Sci 9: 371-400

$\mathrm{Hu}$ B, Steriade M, Deschenes M (1989) The effects of brainstem peribrachial stimulation on perigeniculate neurons: the blockage of spindle waves. Neuroscience 31: 1-12

Joyce JN, Lexow N, Bird E, Winokur A (1988) Organization of dopamine D1 and D2 receptors in human striatum: receptor autoradiographic studies in Huntington's disease and schizophrenia. Synapse 2: 546-557

Kuhl DE, Minoshima S, Fessler JA, Frey KA, Foster NL, Ficaro EP, Weiland DM, Koeppe RA (1996) In vivo mapping of cholinergic terminals in normal aging. Alzheimer's disease and Parkinson's disease. Ann Neurol 40: 399-410

Ladner CJ, Celesia GG, Magnuson J, Lee JM (1995) Regional alterations in M1 muscarinic receptor $-\mathrm{G}$ protein coupling in Alzheimer's disease. J Neuropathol Exp Neurol 54: 783-789

Launer LJ, Jama JW, Ott A, Breteler MMB, Hoes AW, Hofman A (1997) Histamine $\mathrm{H}_{2}$ blocking drugs and the risk for Alzheimer's disease: the Rotterdam study. Neurobiol Aging 18: 257-259 
Leonard S, Adams C, Breese CR, Adler LE, Bickford P, Byerley W, Coon H, Griffith JM, Miller C, Myles-Worsley M, Wagamoto HT, Rollins Y, Stevens KE, Waldo M, Freedman R (1996) Nicotinic receptor function in schizophrenia. Schizophr Bull 22: 431-445

Levy R, Eagger S, Griffiths M, Perry E, Hanavar M, Dean A, Lantos P (1994) Lewy bodies and response to tacrine in Alzheimer's disease. Lancet 343: 176

Lindstrom J, Anand R, Gerzanich V, Peng X, Wang F, Wells G (1996) Structure and function of neuronal nicotinic acetylcholine receptors. Prog Brain Res 109: 125-140

McCormick DA, Prince DA (1987) Actions of acetylcholine in the guinea pig and cat medial and lateral geniculate nuclei in vitro. J Physiol 392: 147-165

McKeith IG, Fairbairn AF, Perry RH, Thompson P, Perry EK (1992) Neuroleptic sensitivity in patients with senile dementia of Lewy body type. Br Med J 305: 673-678

McKeith IG, Galasko D, Kosaka K, Perry EK, Dickson DW, Hansen LA, Salmon DP, Lowe J, Mirra SS, Byrne EJ, Lennox G, Quinn NP, Edwardson JA, Ince PG, Bergeron C, Burns A, Miller BL, Lovestone S, Collerton D, Jansen EN, Ballard C, de Vos RA, Wilcock GK, Jellinger KA, Perry RH (1996) Dementia with Lewy bodies: diagnostic criteria and pathological guidelines. Report of the Consortium on Dementia with Lewy bodies. Neurology 47: 1113-1124

McEvoy JP, Lindgren J (1996) Smoking and schizophrenia. Drug Dev Res 38: 263-266

Manning KA, Wilson JR, Uhlrich DJ (1996) Histamine-immunoreactive neurones and their innervation of visual regions in the cortex, tectum and thalamus in the primate Macaca mulatta. J Comp Neurol 373: 271-282

Martinez-Mir MI, Pollard H, Moreau J, Arrang JM, Ruat M, Traiffort E, Schwartz JC, Palacios JM (1990) Three histamine receptors $\left(\mathrm{H}_{1}, \mathrm{H}_{2}\right.$ and $\left.\mathrm{H}_{3}\right)$ visualised in the brain of human and non-human primates. Brain Res 526: 322-327

Mirra SS, Hegman A, McKeel D, Sclerij SH, Crain BJ, Brownlee LM, Nogel FS, Hughes JP, van Beele G, Berg L (1991) The consortium to establish a registry for Alzheimer's disease (CERAD), part II. Standardisation of the neuropathologic assessment of Alzheimer's disease. Neurology 41: 479-480

Nakamura S, Takemura M, Ohnishi K, Suenaga T, Nishimura M, Akiguchi I, Kimura J, Kimura T (1993) Loss of large neurons and occurrence of neurofibrillary tangles in the tuberomammillary nucleus of patients with Alzheimer's disease. Neurosci Lett 151: 196-199

Nitsch RM, Growdon JH (1994) Role of neurotransmission in the regulation of amyloid$\beta$-protein precursor processing. Biochem Pharmacol 47: 1275-1284

Ogawa N, Mizukawa K, Asanuma M, Kanazawa I (1993) Abnormalities in muscarinic cholinergic receptors and their G-protein coupling systems in the cerebral frontal cortex in Alzheimer's disease. Arch Gerontol Geriatr 17: 77-89

Parent A (1990) Extrinsic connections of the basal ganglia. Trends Neurosci 13: 254-258

Perry EK, Perry RH (1995) Acetylcholine and hallucinations: disease related compared to drug-induced alterations in human consciousness. Brain Cogn 28: 240-258

Perry EK, Marshall E, Kerwin J, Smith CJ, Jabeen S, Cheng AV, Perry RH (1990) Evidence of a monoaminergic: cholinergic imbalance related to visual hallucinations in Lewy body dementia. J Neurochem 55: 1454-1456

Perry EK, Marshall E, Perry RH, Irving D, Smith CJ, Blessed G, Fairbairn AF (1990) Cholinergic and dopaminergic activities in senile dementia of Lewy body type. Alzheimer Dis Assoc Disord 4 (2): 87-95

Perry EK, Johnson M, Kerwin JM, Piggott MA, Court JA, Ince PG, Shaw PJ, Brown A, Perry RH (1992) Convergent cholinergic activities in aging and Alzheimer's disease. Neurobiol Aging 13: 393-400

Perry EK, Morris CM, Court JA, Cheng A, Fairbairn AF, McKeith IG, Irving D, Brown A, Perry RH (1995) Alteration in nicotine binding sites in Parkinson's disease, Lewy body dementia and Alzheimer's disease: possible index of early neuropathology. Neuroscience 64: 385-395

Perry RH, Irving D, Blessed G, Perry EK, Fairbairn AF (1989) Senile dementia of Lewy body type and the spectrum of Lewy body disease. Lancet i: 1088 
Perry RH, Irving D, Blessed G, Fairbairn AF, Perry EK (1990) Senile dementia of Lewy body type: a clinically and pathologically distinct form of Lewy body dementia in the elderly. J Neurol Sci 95: 119-139

Rogers SL, Friedhoff LT (1996) The efficacy and safety of donepezil in patients with Alzheimer's disease: results of a US multicentre randomized, doubleblind, placebo controlled trial. Dementia 7: 293-303

Rowell PP (1995) Nanomolar concentrations of nicotine increase the release of $\left[{ }^{3} \mathrm{H}\right]$ dopamine from rat striatal synaptosomes. Neurosci Lett 189: 171-175

Schenck CH, Bundlie SR, Mahowald MW (1996) Delayed emergence of a Parkinsonian disorder in $38 \%$ of 29 older men initially diagnosed with idiopathic rapid eye movement sleep behavioural disorder. Neurology 46: 388-393

Schneider C, Risser D, Kirchner L, Kitzmuller E, Cairns N, Prast H, Singewald N, Lubec G (1997) Similar deficits of central histaminergic system in patients with Down syndrome and Alzheimer's disease. Neurosci Lett 222: 183-186

Seeman P, Bzowej NH, Guan HC, Bergeron C, Reynolds GP, Bird ED, Riederer P, Jellinger K, Tourtellotte WW (1987) Human brain D1 and D2 dopamine receptors in schizophrenia, Alzheimer's, Parkinson's and Huntington's diseases. Neuropsychopharmacology 1 (1): 5-15

Smith CJ, Perry EK, Perry RH, Fairbairn AF, Birdsall NJM (1987) Guanine nucleotide modulation of muscarinic receptor binding in postmortem human brain - a preliminary study in Alzheimer's disease. Neurosci Lett 82: 227-232

Spurden DP, Court JA, Lloyd S, Oakley A, Perry R, Pearson C, Pullen RGL, Perry EK (1997) Nicotinic receptor distribution in the human thalamus: autoradiographical localisation of $\left[{ }^{3} \mathrm{H}\right]$ nicotine and $\left[{ }^{125} \mathrm{I}\right] \alpha$-bungarotoxin binding. J Chem Neuroanat 13: 105-113

Stevens KE, Waldo M, Freedman R (1996) Nicotinic receptor function in schizophrenia. Schizophr Bull 22: 431-445

Tatsch K, Schwarz J, Mozley PD, Linke R, Pogarell O, Oertel WH, Fieber RS, Hahn K, Kung HF (1997) Relationship between clinical features of Parkinson's disease and presynaptic dopamine transporter binding assessed with [123I] IPT and single-photon emission tomography. Eur J Nucl Med 24 (4): 415-421

Thompson J, Thomas N, Singleton A, Piggott M, Lloyd S, Perry EK, Morris CM, Perry RH, Ferrier IN, Court JA (1997) D2 dopamine receptor gene (DRD2) Taq 1 polymorphism reduced dopamine D2 receptor binding in the human striatum associated with the A1 allele. Pharmacogenetics 7: 479-484

Traiffort E, Pollard H, Moreau J, Ruat M, Schwartz JC, Martinez-Mir MI, Palacios JM (1992) Pharmacological characterization and autoradiographic localization of histamine $\mathrm{H} 2$ receptors in human brain identified with [125I]iodoaminopotentidine. J Neurochem 59: 290-299

Turner RS, Chervin RD, Frey KA, Minoshima S, Kuhl DE (1997) Probable diffuse Lewy body disease presenting as REM sleep behaviour disorder. Neurology 49: 523-527

Vehiyama M, Isse K, Tanaka K, Yakota N, Hamamoto M, Aida S, Ito Y, Yoshimura M, Okawa M (1995) Incidental Lewy body disease in a patient with REM sleep behaviour disorder. Neurology 45: 709-712

Warpman V, Alafuzoff I, Nordberg A (1993) Coupling of muscarinic receptors to GTP proteins in postmortem human brain - alterations in Alzheimer's disease. Neurosci Lett 150: 39-43

Xuereb JH, Perry RH, Candy JM, Bonham JR, Perry EK, Marshall E (1990) Parameters of cholinergic neurotransmission in the thalamus in Parkinson's disease and Alzheimer's disease. J Neurol Sci 99: 185-197

Authors' address: Prof. Dr. E. Perry, Medical Research Council Neurochemical Pathology Unit, Newcastle General Hospital, Westgate Road, Newcastle upon Tyne, NE4 6BE, United Kingdom. 